\title{
Konsep Dakwah Dalam Memelihara Dan Pemberdayaan Masyarakat Di Sekitar Hutan (Studi Kasus Di Kabupaten Kerinci)
}

\author{
Ivan Sunata \\ IAIN Kerinci \\ ivansunata.ma@gmail.com
}

\begin{abstract}
Propagation as a pillar of Islam in conveying God's revelation must be interpreted broadly, not just propaganda materials related subject matter (tawhid) but also about the preservation of nature and the welfare of the people (society). Forests should be managed jointly between the public and the government that maintained continuity, while people living in the vicinity to prosperous. This research is field research field with qualitative research type, research method used is action research or action study with participatory approach, this approach emphasizes the importance of dialogue process in research. In this case can be seen how the concept of da'wah in the maintenance and empowerment of communities around the forest in Kerinci district
\end{abstract}

Keywords: The concept of Da'wah, Maintaining Forest, Community Empowerment

\begin{abstract}
Abstrak:
Dakwah sebagai pilar Islam dalam menyampaikan wahyu Allah harus diartikan secara luas, materi dakwah tidak hanya terkait hal-hal pokok (tauhid) tetapi juga menyangkut kelestarian alam dan kesejahteraan umat (masyarakat). Hutan harus dikelola secara bersama-sama antara masyarakat dan pemerintah sehingga terjaga kelestariannya, sementara masyarakat yang tinggal di sekitarnya tersejahterakan. Penelitian ini bercorak field research dengan jenis penelitian kualitatif, Metode penelitian yang digunakan adalah action research atau kaji tindak dengan pendekatan participatory, pendekatan ini menekankan pentingnya proses dialog dalam penelitian. Dalam
\end{abstract}


hal ini dapat dilihat bagaimana konsep dakwah dalam pemeliharaan dan pemberdayaan masyarakat di sekitar hutan di kabupaten kerinci

Kata Kunci: Konsep Dakwah, Memelihara Hutan, Pemberdayaan Masyarakat

\section{Pendahuluan}

A.Halim dalam Dakwah Pemberdayaan Masyarakat memaparkan beberapa konsep pembangunan manusia seutuhnya (insan kamil dalam perspektif agama, yakni sebagai berikut;

"1). Pengembangan masyarakat dapat dilihat sebagai peletakan sebuah tatanan sosial dimana manusia secara adil dan terbuka dapat melakukan usaha-usahanya sebagai perwujudan atas kemampuan dan potensi yang dimilikinya sehingga kebutuhannya (material dan spiritual) dapat terpenuhi.

2). Pengembangan masyarakat tidak dilihat sebagai suatu proses pemberian dari pihak yang memiliki sesuatu kepada pihak yang tidak memiliki.

3) Pengembangan masyarakat mesti dilihat sebagai sebuah proses pembelajaran kepada masyarakat agar mereka dapat secara mandiri melakukan upaya-upaya perbaikan kualitas kehidupannya.

4) Pengembangan masyarakat tidak mungkin dilaksanakan tanpa keterlibatan secara penuh oleh masyarakat itu sendiri. Partisipasi bukan sekedar diartikan dengan kehadiran mereka dalam suatu kegiatan saja, tetapi juga dipahami sebagai kontribusi mereka dalam setiap tahapan yang mesti dilalui oleh suatu program kerja pengembangan masyarakat. 5) Tuntutan akan keterlibatan masyarakat dalam suatu program pengembangan tidak mungkin dilakukan tatkala masyarakat itu sendiri tidak memiliki daya ataupun bekal yang cukup. ${ }^{1}$

Dari asumsi dasar tersebut lahirlah hak, nilai, dan keyakinan dalam masyarakat yang harus dihormati, antara lain sebagai berikut:

1 Fakultas dakwah IAIN Sunan Ampel Surabaya, Dakwah Pemberdayaan Masyarakat Paradigma Aksi Metodologi (Yogyakarta: Pustaka Pesantren, 2005), cet.ke1, 4 
1). Hak menentukan keputusan-keputusan yang mempengaruhi kesejahteraan mereka. Hak ini muncul karena adanya keyakinan bahwa masyarakat memiliki kemampuan (viabilitas) memecahkan masalahnya sendiri.

2). Masyarakat mempunyai hak untuk berusaha menciptakan lingkungan yang diinginkannya dan menolak suatu lingkungan yang dipaksakan dari luar. Penciptaa lingkungan sesuai keinginan ini tetap didasari ketenangan dan ketenteraman lingkungan lainnya sehingga dalam diri masyarakat terjadi interaksi sosial aktif dan adaptif.

3). Masyararakat harus diyakini mampu bekerjasama secara rasional dalam bertindak untuk mengidentifikasi masalah dan kebutuhan komunitasnya, serta bertindak dalam menggapai tujuan secara bersama. Dengan demikian, dalam pembangunan masyarakat penting untuk memperhatikan karakteristik komunitas dan masyarakat pada umumnya, terutama yang berkaitan dengan penentuan dan kontribusi kekuasaan.2

Berdasarkan beberapa konsep dan ciri pemberdayaan yang telah dipaparkan di atas, maka untuk menjalankan amanat Undang-undang Kehutanan khususnya di Kabupaten Kerinci, maka Pemerintah Indonesia melalui Kementerian Kehutanan telah memberikan kewenangan pada Kabupaten Kerinci untuk membentuk Hutan Hak Adat, dimana sampai saat ini Kerinci telah memiliki 3 Hutan Hak Adat, yaitu Hutan Adat Temedak Desa Keluru Kecamatan Keliling Danau, Hutan Adat Nenek Limo Hiang Tinggi Nenek Empat Bentung Kuning Muaro Air Dua Hiang, dan Hutan Adat Hulu Air Lempur Lekuk 50 Tumbi.

Tujuan dibentuknya hutan adat adalah untuk kelestarian, keserasian dan keseimbangan ekosistem yang meliputi unsur lingkungan, sosial dan budaya, dimana pengelolaannya diserahkan kepada masyarakat hukum adat. ${ }^{3}$ Namun dalam perjalanannya, Lembaga Hutan Hak Adat belum berkembang dengan pesat, baik dari segi surflus keuangan, peningkatan dan pengembangan kapasitas organisasi dan anggota, maupun kerjasama dengan organisasi lain.

\footnotetext{
${ }^{2}$ Ibid, 7-8

${ }^{3}$ Ibid, h. 24
} 
Pemanfaatan hutan hak adat masih dilakukan secara tradisional, sendiri, tanpa dukungan dari pihak lain. Meski demikian, sejak dibentuk Lembaga Hutan Hak Adat Desa Keluru tetap ada sampai sekarang dan masih menjalankan fungsi organisasinya, baik memfasilitasi kebutuhan masyarakat terhadap hasil hutan maupun melestarikan hutan itu sendiri. Hal ini berbeda dengan Kelompok Konservasi Desa (KKD) terutama di Desa Belui Tinggi, dimana sampai saat ini, organisasi masyarakat yang dibentuk ICDP (International Continental Scientific Drilling program) tidak melakukan kegiatan konservasi lagi karena terlalu bergantung kepada perguliran dana (revolving fund) dari pemerintah dan pihak ketiga.

Lembaga Hutan Hak Adat dan Kelompok Konservasi Desa sebagaimana dibahas di atas hanya merupakan beberapa contoh dan masih banyak kelompok-kelompok masyarakat pengelola hutan baik yang dibentuk oleh pemerintah, lembaga swadaya masyarakat tidak berlanjut dan berfungsi sebagaimana mestinya. Hal ini tentunya memberikan sedikit gambaran bahwa program pemberdayaan masyarakat di sekitar hutan yang dikelola oleh kelompok masyarakat lokal tidak berjalan efektif karena berbagai kendala.

Berdasarkan data-data yang telah dikemukakan di atas, maka perlu dikaji tentang "Konsep Dakwah Dalam Memelihara dan Memberdayakan Masyarakat di Sekitar.”

Penelitian ini bercorak field research dengan jenis penelitian kualitatif, karena ingin mengungkapkan fenomena, fakta, realita, kenyataan yang terjadi pada objek penelitian secara holistik/utuh, dan mendalam.

Metode penelitian yang digunakan adalah action research atau kaji tindak dengan pendekatan participatory, pendekatan ini menekankan pentingnya proses dialog dalam penelitian, karena mempunyai relevansi khusus dalam kaitan dengan identifikasi masalah. Pendekatan participatory mempertahankan bahwa masalah hendaknya tidak dirumuskan oleh para pakar, tetapi harus didasarkan pada dialog (dialog dengan subjek penelitian, dialog dengan peneliti dan analisis lain, dialog 
dengan pengambil keputusan dan para pejabat kunci, dan dialog dengan masyarakat umum). ${ }^{4}$

Sumber data dalam penelitian ini terdiri dari: Balai Besar Taman Nasional Kerinci Seblat (TNKS), Dinas Kehutanan Kabupaten Kerinci, Lembaga Swadaya Masyarakat dan Lembaga Masyarakat Pengelola Hutan (Hutan Adat dan Kelompok Konservasi Desa).

Pengumpulan data sekunder dilakukan dengan cara studi dokumentasi, sedangkan untuk mendapatkan data primer penulis melakukan wawancara terstruktur (interview guide) dan pengamatan langsung (direct observation) serta diskusi kelompok terfokus (focus group discussion/FGD).

\section{Islam dan Lingkungan Hidup}

Islam sebagai agama yang membawa konsep Rabmatan lil 'Alamin sangat memperhatikan faktor lingkungan, hal ini dapat dilihat dari firman Allah yang melarang umat manusia untuk berbuat kerusakan di bumi sebagaimana yang tercantum pada al-Qur'an surat Ar-Rum ayat 41 sebagai berikut:

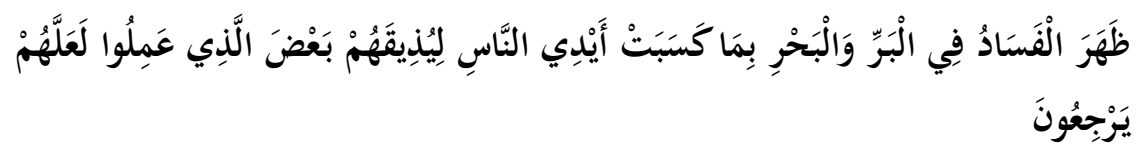

"Telah nampak kerusakan di darat dan di laut disebabkan karena perbuatan tangan manusia, supaya Allah merasakan kepada mereka sebahagian dari (akibat) perbuatan mereka, agar mereka kembali (ke jalan yang benar). ${ }^{, 5}$

Untuk mengajak manusia kembali ke jalan yang benar, diperlukan kegiatan dakwah yang pelakunya disebut $d \bar{a}^{-} i$, yakni orang yang bertugas mengajak manusia kepada agama Islam atau mazhabnya. ${ }^{6}$

${ }^{4}$ Moh. Ali Aziz, Rr. Suhartini, A. Halim, Dakwah Pemberdayaan Masyarakat Paradigma Aksi metodologi (Yogyakarta: Pustaka Pesantren, 2005), ce.ke-1, 253

5 Al-Qur'an dan Terjemahannya (Jakarta: Yayasan Penyelenggara Penterjemah/Pentafsir Al-Qur'an, 1971), 647

${ }^{6}$ Salmadanis, Da'i dan Kepemimpinan (Jakarta Barat: 2004), cet.ke-1, 21-24 
Dalam konteks pemberdayaan masyarakat, da’i yang dimaksud adalah dái sebagai perantara (broker) yakni $d \bar{a} \dot{i}$ yang menghubungkan individu atau kelompok dalam masyarakat yang membutuhkan bantuan/layanan namun tidak tahu dimana dan bagaimana mendapatkan bantuan/layanan tersebut dengan institusi yang menyediakannya. ${ }^{7}$ Atau $d \bar{a} i$ sebagai perencana sosial, yaitu $d \bar{a} \dot{i}$ yang mengumpulkan data mengenai masalah sosial yang terjadi dalam masyarakat, menganalisanya dan menyajikan alternatif tindakan yang rasional untuk penanganan masalah tersebut. ${ }^{8}$

Dalam pandangan Islam, manusia disamping sebagai salah satu makhluk Tuhan, ia sekaligus sebagai wakil (khalifah) Tuhan dimuka bumi sebagaimana yang terdapat dalam al-Quran Surat Al-An'am ayat 165 sebagai berikut:

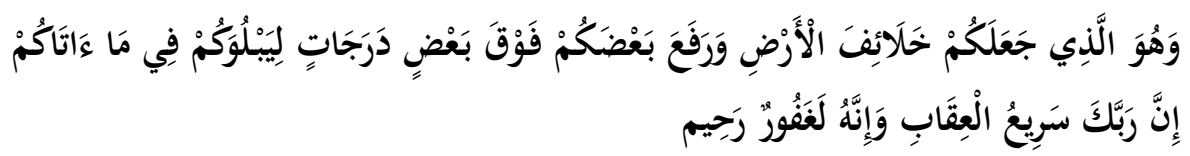

"Dan Dialah yang menjadikan kamu penguasa-penguasa di bumi dan Dia meninggikan sebahagian kamu atas sebahagian (yang lain) beberapa derajat, untuk mengujimu tentang apa yang diberikan-Nya kepadamu. Sesunggubnya Tuhanmu amat cepat siksaan-Nya, dan sesunggubnya Dia Maha Pengampun lagi Maha Penyayang."

Sebagai wakil Allah, maka manusia harus bisa merepresentasikan peran Allah terhadap alam semesta termasuk bumi seisinya antara lain dengan memelihara (al-rab) dan menebarkan rahmat (rahmatan) di alam semesta. Oleh karena itu kewajiban manusia terhadap alam dalam rangka pengabdiannya kepada Allah SWT adalah melakukan pemeliharaan terhadap alam, termasuk pemeliharaan diri sendiri (bifdzun nafs) untuk menjaga keberlangsungan kehidupan di alam.

${ }^{7}$ Wakidul Kohar, Disain Pengembangan Masyarakat Islam, Hand Out, (Tidak Diterbitkan) (Padang: IAIN Imam Bonjol Padang, 2011), 6

${ }^{8}$ Ibid, 7

${ }^{9}$ Al-Qur'an dan Terjemahannya, Op.Cit, 217 


\section{Kerusakan Hutan}

Faktanya saat ini kerusakan hutan yang terjadi sudah sampai pada tahap yang serius dan mengancam eksistensi planet bumi dimana manusia, hewan dan tumbuhan bertempat tinggal dan melanjutkan kehidupannya.

Menurut catatan pada tahun 2000, seluas 50,76 juta hektar lahan kawasan hutan sudah mengalami kerusakan, dengan rincian 34,717 hektar hutan produksi, 6,961 juta hektar hutan konservasi dan 9,09 juta hektar hutan lindung. ${ }^{10}$ Sementara pada tahun 2006, luas hutan yang rusak dan tidak dapat berfungsi optimal telah mencapai 59,6 juta hektar dari 120,35 juta hektar kawasan hutan di Indonesia, dengan laju deforestasi dalam lima tahun terakhir mencapai 2,83 juta hektar per tahun.

Kerusakan hutan juga terjadi di Kabupaten Kerinci, meski tidak ada data resmi mengenai kerusakan hutan di daerah ini. namun berdasarkan laporan Antara, 30 persen dari 1,4 juta hektar total luas Taman Nasional Kerinci Seblat yang berada di Kabupaten Kerinci berisiko tinggi rusak dan tergradasi karena berbagai faktor, baik dikarenakan penebangan liar atau kepentingan ekonomi lainnya. ${ }^{11}$

\section{Konsep Pengelolaan Hutan Dalam Kajian Dakwah}

Guna mengatasi kerusakan hutan lebih jauh, konsep pengelolaan hutan sebaiknya dikembalikan kepada ajaran Islam, dimana Islam memandang lingkungan sebagai bagian yang tidak terpisahkan dari keimanan seseorang terhadap Tuhannya. Dengan kata lain, perilaku manusia terhadap lingkungan merupakan manifestasi dari keimanan seseorang.

Islam melarang pemanfaatan alam (sumberdaya alam) yang melampaui batas atau berlebihan. Pemanfaatan (eksploitasi) sumberdaya alam yang berlebihan akan menguras sumberdaya alam yang

10 Transtoto Handadhari, Kepedulian ynag Terganjal; Menguak Belantara Permasalahan Kehutanan Indonesia (Jakarta: PT Elex Media Computindo, 2009), cet.ke-1, 7

11 Ancaman Kerusakan TNKS Masih Tinggi, 10 Nopember 2009, dalam http://www.antara.com, diakses pada 7 Desember 2011 
bersangkutan hingga habis tak tersisa, sehingga hak-hak untuk memanfaatkan sumberdaya alam bagi generasi yang akan datang terabaikan. Pesepektif Islam dalam kaitannya dengan masalah sesuai dengan Firman Allah SWT sebagai berikut:

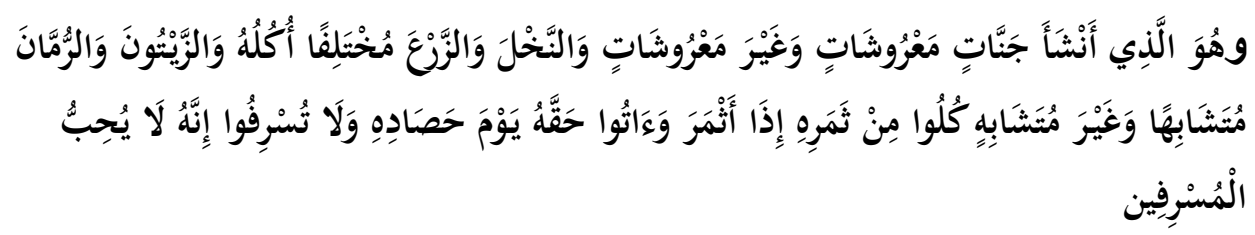

"Dan Dialah yang menjadikan kebun-kebun yang berjunjung dan yang tidak berjunjung, pohon kurma, tanam-tanaman yang bermacam-macam buahnya, zaitun dan delima yang serupa (bentuk dan warnanya), dan tidak sama (rasanya). Makanlah dari buahnya (yang bermacam-macam itu) bila dia berbuah, dan tunaikanlah haknya di hari memetik hasilnya (dengan dikeluarkan rakatnya); dan janganlah kamu berlebih-lebihan. Sesunggubnya Allah tidak menyukai orangorang yang berlebih-lebiban."12 (Q.S Al-'An'am : 141)

Pengelolaan dan pola interaksi manusia dengan alam serta lingkungan hidup ada tiga, yaitu: Pertama al-intifa', Allah mempersilakan manusia untuk mengambil manfaat dan mendayagunakan hasil alam dengan sebaik-baiknya demi kemakmuran dan kemaslahatan. Kedua ali'tibar, manusia dituntut untuk memikirkan dan menggali rahasia dibalik ciptaan Allah serta dapat mengambil pelajaran dari berbagai kejadian dan peristiwa alam. Ketiga al-ishlah, manusia diwajibkan untuk terus menjaga dan memelihara kelestarian lingkungan itu. ${ }^{13}$

Oleh karena itu, dalam rangka menyusun fiqh lingkungan (fiqh al-bi'ab), ada beberapa hal yang perlu diperhatikan, yaitu sebagai berikut: ${ }^{14}$ Pertama, rekonstruksi makna khalifah. Al-Qur'an menegaskan bahwa menjadi khalifah di muka bumi ini tidak untuk melakukan perusakan dan pertumpahan darah, tetapi untuk membangun kehidupan

${ }^{12}$ Al-Qur'an dan Terjemahannya, Op.Cit,, 212

${ }^{13}$ MS Ka'ban, Pengelolaan Lingkungan Hidup Dalam Perspektif Islam, Millah Vol. VI, No. 2, 2007, h. 4, diakses pada 19 Maret 2012

14 Hatim Gazali, Fiqh Ramah Lingkungan, 2007, dalam http:// www.bebasbanjir2025.wordpress.com, diakses pada 15 Januari 2012 
yang damai, sejahtera, dan penuh keadilan. Manusia yang melakukan kerusakan di muka bumi ini secara otomatis mencoreng atribut manusia sebagai khalifah, ${ }^{15}$ karena walaupun alam diciptakan untuk kepentingan manusia, ${ }^{16}$ tetapi tidak diperkenankan menggunakannya secara semenamena.

Kedua, ekologi sebagai doktrin ajaran. Artinya, menempatkan wacana lingkungan bukan pada cabang (furü ), tetapi termasuk doktrin utama (ushü) ajaran Islam, sebagaimana yang dijelaskan oleh Yusuf Qardhawi dalam Ri'âyah al-Bi'ah fiy Syaríab al-Isläm (2001), bahwa memelihara lingkungan sama halnya dengan menjaga lima tujuan dasar Islam (maqāshid al-syarìab). Sebab, kelima tujuan dasar tersebut bisa terejawantah jika lingkungan dan alam semesta mendukungnya. Oleh karena itu, memelihara lingkungan sama hukumnya dengan maqäshid alsyari'ah. Kaidah ushül fiqh disebutkan, mà là yatimmu al-wäjì illā bibi fabuwa wäjibun (sesuatu yang membawa kepada kewajiban, maka sesuatu itu hukumnya wajib).

Ketiga, tidak sempurna iman seseorang jika tidak peduli lingkungan. Keberimanan seseorang tidak hanya diukur dari banyaknya ritual di tempat ibadah. Tapi, juga menjaga dan memelihara lingkungan merupakan hal yang sangat fundamental dalam kesempurnaan iman seseorang. Nabi bersabda bahwa kebersihan adalah bagian dari iman.

Keempat, perusak lingkungan adalah kafir ekologis (kufr al-bìab). Di antara tanda-tanda kebesaran Allah adalah adanya jagad raya (alam semesta) ini. Karena itulah, merusak lingkungan sama halnya dengan ingkar (kafir) terhadap kebesaran Allah. ${ }^{17}$

Selain itu, kita perlu memperjuangkan politik hijau (green politic), sebuah gerakan mendampingi pembangunan agar berperspektif

${ }^{15}$ QS. al-Baqarah ayat 30:

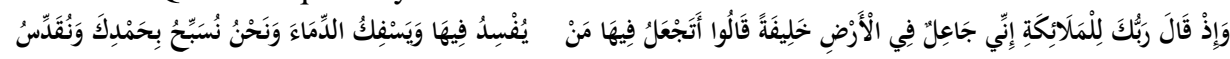

${ }^{16}$ QS. Luqman ayat 20:

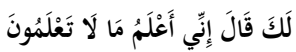

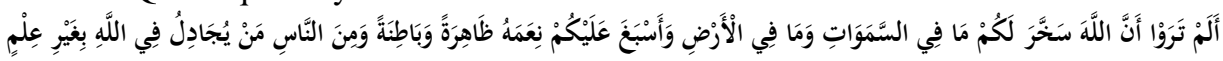

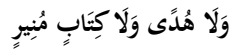

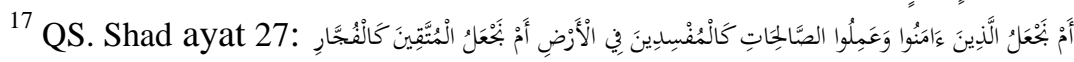


ekologis. Kebijakan-kebijakan politik yang anti-ekologi, mekanistik, dan materialistik diarahkan menuju kebijakan politik yang sadar lingkungan (ecological politic). Hal ini penting karena kerusakan alam yang sedemikian parah tidak mungkin hanya diselesaikan melalui pendekatan agama. Akan tetapi, perlu pendekatan yang komprehensif. Mulai dari agama, ekonomi, politik, budaya, dan sosial bersatu padu menangani krisis ekologis ini.

\section{Hutan dan Kajian Dakwah Pemberdayaan Masyarakat di Sekitarnya}

Hutan berdasarkan berdasarkan konsep harta dan kepemilikan di dalam Islam dikategorikan sebagai kepemilikan umum (milkiyyatul 'âm) dan kepemilikan negara (milkiyyatul daulab), ${ }^{18}$ yaitu sarana-sarana umum yang diperlukan oleh seluruh kaum muslim dalam kehidupan seharihari, seperti kayu bakar, penggunaan untuk bangunan dan rumah serta sumber mata pencaharian.

Oleh karena itu, Negara mempunyai kewajiban untuk mensejahterakan masyarakat dengan memanfaatkan kawasan hutan tanpa merusak ekosistemnya. Hal tersebut sejalan dengan yang diterapkan pada Negara Indonesia dimana pemberdayaan masyarakat di sekitar hutan merupakan salah satu wujud pelaksanaan konstitusi negara. Pasal 33 UUD 1945 mengamanatkan agar penguasaan negara atas kekayaan alam (hutan) ditujukan sebesar-besar kemakmuran rakyat. ${ }^{19}$ Hal ini diatur lebih lanjut dalam Undang-undang Kehutanan No. 41 Tahun 1999 pasal 2: "Penyelenggaraan kehutanan berasaskan manfaat dan lestari, kerakyatan, keadilan, kebersamaan, keterbukaan, dan keterpaduan." 20

Berdasarkan undang-undang tersebut, maka pemerintah harus mengakomodir kepentingan berbagai kelompok baik rimbawan, petani,

\footnotetext{
${ }^{18}$ Elvin Gunawan, Konsep Islam tentang Pengelolaan Hutan, 2008, dalam http:// www.elvingunawan.multiply.com, diakses pada 1 November 2011

${ }^{19}$ Yaser Arafat, UUD RI 1945 dan Perubahannya (Jakarta: Permata Press, 2000), 58

${ }^{20}$ IKAPI, Himpunan Peraturan Perundang-undangan Kehutanan dan Illegal Logging, (Bandung: Pustaka Media, 2011) h. 14
} 
peternak, peramu hasil hutan, masyarakat hutan adat maupun kepentingan lainnya. Mereka harus diberdayakan agar kesejahteraan hidupnya meningkat dan tidak merusak hutan. Untuk mencapai hal tersebut maka akses dan hak pemanfaatan atas berbagai kategori hutan harus diatur sebaik-baiknya bagi semua kelompok.

Disamping itu, dalam mengelola hutan pemerintah harus menerapkan konsep Cooperatif Management atau yang disingkat CoManagement seperti yang diungkapkan Pomeroy dan Williams (1994) bahwa konsep tersebut mampu menampung kepentingan masyarakat maupun kepentingan pengguna lainnya. ${ }^{21}$

Jadi pengelolaan hutan yang berbasis masyarakat adalah suatu sistem pengelolaan sumberdaya alam dimana masyarakat lokal terlibat secara aktif dalam proses pengelolaan sumberdaya alam yang terkandung di dalamnya. Pengelolaan disini meliputi berbagai dimensi seperti perencanaan, pelaksanaan, serta pemanfaatan hasil-hasilnya.

\section{Implikasi Pemberdayaan Masyarakat di Sekitar Hutan}

Untuk mengimplikasikan konsep Co-Management dalam pengelolaan hutan, di Kabupaten Kerinci telah dikembangkan dua model pengelolaan hutan, yang pertama adalah Hutan Hak Adat (HHA) yang tumbuh dari masyarakat, dan yang kedua melalui programprogram pemerintah seperti program Kesepakatan Konservasi Desa $(\mathrm{KKD})$.

Kedua model pengelolaan hutan ini, pada dasarnya baik karena bertujuan untuk menjaga kelestarian hutan dan mensejahterakan masyarakat di sekitarnya. Namun setelah diteliti dalam sebuah kajian ilmiah, masing-masing model pengelolaan hutan tersebut mempunyai kelebihan dan kekurangan tersendiri.

Analisis kelebihan dan kekurangan masing-masing model pengelolaan hutan tersebut penulis simpulkan sebagai berikut:

${ }^{21}$ Zalfa Akilah, Pengelolaan Terumbu Karang, 2011, dalam http://www. zalfaakilah.multiply.com, diunduh tanggal 19 Maret 2012 


\section{Hutan Hak Adat}

Dari segi keberfungsian terhadap pengembangan organisasi, pengelolaan Lembaga Hutan Adat Desa Keluru Kecamatan Keliling Danau Kabupaten Kerinci yang masih dilaksanakan dengan sistem tradisional, yakni menempatkan seorang Rio Ganum (tuan tanah) sebagai penguasa tunggal Hutan Adat tidak efektif dalam melakukan pemberdayaaan masyarakat.

Hal ini disebabkan beberapa hal, diantaranya: (1) Pemimpin tidak dipilih berdasarkan kemampuan tetapi berdasarkan garis keturunan; (2) tidak adanya pengelompokan, spesialisasi kerja sehingga semua kegiatan dikendalikan oleh satu orang yang sumber daya manusianya terbatas.

Namun dari segi keberfungsian terhadap konservasi hutan, Lembaga Hutan Adat sangat efektif menjaga hutan agar tetap lestari karena kepemimpinan adat memiliki kharismatik tersendiri, sehingga masyarakat patuh dan takut untuk melanggar aturan, ditambah lagi dengan ketatnya sanksi adat dan sosial yang berlaku.

Sistem nilai yang berkembang pada masyarakat menganggap bahwa hutan sebagai bagian yang tak terpisahkan dari kehidupan masyarakat yang mampu menopang keberlansungan hidup dan meningkatkan kesejahteraan mereka, sehingga hubungan manusia dengan alam (hutan) berjalan harmonis, saling menguntungkan satu sama lain.

\section{Kesepakatan Konservasi Desa}

Pengelolaan Kesepakatan Konservasi Desa yang dilaksanakan secara terstruktur membuat program-program organisasi mudah tercapai, karena adanya kerjasama antar pengurus, anggota, dan dibina oleh beberapa pihak.

Namun karena tumbuh dari sebuah program/proyek, Kesepakatan Konservasi Desa tidak berlanjut karena hilangnya pengawasan dari lembaga donor dan lembaga terkait lainnya bersamaan dengan dihentikannya proyek/program tersebut. Sementara generasi penerus yang diharapkan bisa melanjutkan program-program tersebut tidak dibekali dengan pendidikan dan 
pelatihan yang memadai sehingga kegiatan pemberdayaan terbentur pada satu generasi tertentu.

Program KKD yang diharapkan bisa menjauhkan masyarakat dari interaksi negatif dengan hutan tidak tercapai, terutama setelah berakhirnya proyek, karena tidak tumbuh dari hati nurani masyarakat.

Sistem nilai yang berkembang pada masyarakat menganggap bahwa hutan sebagai transaksional, oleh karena itu interaksi manusia dengan hutan selalu diukur dengan uang, ketika uang atau sebuah program tidak ada, masyarakat kembali merusak hutan.

\section{Kesimpulan}

Dari pembahasan di atas dapat disimpulkan bahwa, kerusakan hutan di Indonesia sudah mencapai titik yang parah, karena kegiatan illegal logging dan sebagainya. Guna mengatasi hal tersebut, sudah saatnya negara menjalankan sistem co-management (pengelolaan bersama) antara pemerintah dan masyarakat sehingga kepentingan seluruh kelompok terakomodir, dalam arti kata hutan terjaga, masyarakat sejahtera.

Dalam hal ini konsep dakwah dan pengembangan masyarakat perlu sekali di terapkan, walaupun pelaksanaan dilakukan oleh pemerintah, namun secara umum konsep dakwah dan pengembangan masyarakat bertujuan untuk menjadikan masyarakat sejahtera sesuai dengan tuntunan dakwah

\section{Saran}

1. Pelibatan masyarakat adat dalam manajemen pengelolaan hutan harus menjadi pertimbangan stackholder termasuk pada model kegiatan-kegiatan konservasi saat ini dengan tetap mengutamakan faktor kualitas sumber daya manusia. Pelibatan masyarakat adat dimaksudkan agar para stackholder mampu mengimplementasikan nilai-nilai adat dan sosial seperti kharismatik pemimpin, kepatuhan masyarakat terhadap pemimpin, kepatuhan masyarakat terhadap peraturan dan sebagainya pada program-program pemberdayaan masyarakat dan konservasi hutan. 
2. Penguatan terhadap lembaga-lembaga sosial yang bergerak di bidang kehutanan harus dilakukan oleh pemerintah dan lembaga-lembaga lainnya. Penguatan lembaga dimaksudkan sebagai pemberian dana/pembiayaan. Pembiayaan terhadap lembaga sosial di bidang kehutanan harus dilakukan secara konsisten dan berkesinambungan serta melibatkan dunia internasional, pemerintah baik pusat maupun daerah harus berperan aktif mengajak dunia internasional mengeluarkan investasi mereka dan pembiayaan terhadap lembaga-lembaga sosial yang bergerak di bidang kehutanan. Selain itu juga penguatan terhadap peningkatan sumber daya manusia melalui pendidikan, pelatihan, dan keterampilan.

\section{Daftar Kepustakaan}

Akilah, Zalfa, Pengelolaan Terumbu Karang, 2011, dalam http://www. zalfaakilah.multiply.com,

Al-Qur'an dan Terjemahannya Jakarta: Yayasan Penyelenggara Penterjemah/Pentafsir Al-Qur'an, 1971

Ancaman Kerusakan TNKS Masih Tinggi, 10 Nopember 2009, dalam http://www.antara.com

Arafat, Yaser, UUD RI 1945 dan Perubahannya, Jakarta: Permata Press, 2000

Gazali, Hatim, Fiqh Ramah Lingkungan, 2007, dalam http:// www.bebasbanjir2025.wordpress.com

Gunawan, Elvin, Konsep Islam tentang Pengelolaan Hutan, 2008, dalam http:// www.elvingunawan.multiply.com

Handadhari, Transtoto, Kepedulian ynag Terganjal; Menguak Belantara Permasalahan Kebutanan Indonesia, Jakarta: PT Elex Media Computindo, 2009

IKAPI, Himpunan Peraturan Perundang-undangan Kebutanan dan Illegal Logging, Bandung: Pustaka Media, 2011 
Ka'ban, MS, Pengelolaan Lingkungan Hidup Dalam Perspektif Islam, Millah Vol. VI, No. 2, 2007, h. 4

Kohar, Wakidul, Disain Pengembangan Masyarakat Islam, Hand Out, (Tidak Diterbitkan), Padang: IAIN Imam Bonjol Padang, 2011

Moh. Ali Aziz, Rr. Suhartini, A. Halim, Dakwah Pemberdayaan Masyarakat Paradigma Aksi metodologi, Yogyakarta: Pustaka Pesantren, 2005

Salmadanis, Da’i dan Kepemimpinan, Jakarta Barat: 2004, cet.ke-1, h. 21-24 